\title{
Education as a Means for Social Work with a New Generation of International Migrants
}

\author{
Prof. Dr. Alexander Kuteynikov \\ St. Petersburg State University (SPSU) \\ 1/3, ul. Smolnogo, 9 entrance, Faculty of Sociology of \\ SPSU, St. Petersburg, 191124, Russian Federation \\ a.kuteynikov@spbu.ru
}

\author{
Prof. Dr. Lyudmila Kuznetsova \\ St. Petersburg State University (SPSU) \\ 1/3, ul. Smolnogo, 9 entrance, Faculty of Sociology of \\ SPSU, St. Petersburg, 191124, Russian Federation
}

\author{
Dr. Théogène-Octave Gakuba \\ Haute Ecole de Travail Social de Genève (HETS) \\ 28, rue Prévost-Martin, Case postale 80, 1211 Genève 4, Switzerland
}

\begin{abstract}
The paper analyses some results of the pilot survey of experts on social work with international migrants conducted by a Russian and Swiss research team in 2017 in the framework of a joint project. The focus of the survey is the present situation and prospects of education for international migrants. As stated by experts from Russia, Switzerland and Germany, there are some social factors that cause a widening gap between the existing public and private educational programs and projects for migrants, institutional resources and capacities, on the one hand, and changing requirements, needs of migrants' communities with regard to education, on the other hand. These factors include: changes in the social structure of migrants, politicization of global migration challenges, diversification of non-national communities and groups, digitalization of the sphere of education, transformation of self-perception and selfidentification of migrants. The authors conclude that there is a demand for new educational programs for non-marginalized groups of non-citizens, which would take into account their growing needs for professional, economic, legal knowledge.
\end{abstract}

Keywords-Migration; International Migrants; Non-nationals; Social Work; Integration; Educational Programmes; Educational Institutions

\section{INTRODUCTION}

The paper analyses some results of a pilot sociological survey of experts regarding the situation and prospects of social work with international migrants. It was conducted by the Russian-Swiss research team in 2017 in the framework of the joint project "Creating a model of a multifunctional centre of competencies in social work with migrants under conditions of their growing inflow in Russia and Switzerland to mitigate threats to society, economy, the state". The focus of the study is determined by the contradictory intentions of modern states and societies. On the one hand, they have to be open to global migratory population movements and to develop instruments of work with migrants, while on the other hand, they have to reduce and regulate migration, preserving their own identity.

\section{GENERALS}

The aim of the study was to test the hypothesis stating that different categories of international migrants, including those who are middle- and upper-class, may feel a deficit of cultural capital, as defined by Bourdieu which would prevent their identification, degree of integration into the host society, social mobility [1]. These groups of migrants may experience this deficit as a result of the breaking of social links, economic crises, company closures, loss of status within their ethnic community, and the like, whereas these very groups may be more promising in terms of social impact on them and integrating them in communities. One of the major means of overcoming the aforementioned deficit is education. $M$. Williams and V. Baláž mentioned that "the classic humancapital perspective suggest that immigrants tend to adapt to their host countries via accumulating human capital" [2]. And education is one of the key characteristic of "the capitalization".

Thus, part of the research deals with the issue of international migrants' education which is generally acknowledged as a key challenge in social work with international migrants. As M. Czaika noted, States" "migration policy activism which had started to accelerate in the early 1990s and intensified during 2000s has produced various policy innovation that aim to attend and retain scare skills more effectively" [3]. The research questions raised in this article are as follows: Is, or is not, education a deficit social resource for international migrants? Does education help international migrants to overcome the deficit of other social resources? What kind of education earns a migrant a higher social status - the education one had got before emigration or the education completed in the receiving country/society? Which types and forms of education are most common? Which are most in demand by international migrants? Which 
forms are readily available, or even in excess, and which are in short supply?

\section{PROGRAM OF THE StUdy}

In search of answers to these and some other questions, we conducted expert interviews on the current situation of migrants and prospects of social work with them. The program of the study was developed by the authors in cooperation with colleagues S. Savin and E. Moskalchuk, with participation of A. Yakolenko and E. Kovtun, and incorporating some earlier findings of research projects on attitudes to migrants of different groups of population [4]. The results of some research conducted earlier were also drawn on $[5,6]$. In November and December 2017 during the pilot study 12 experts specializing in the study of migration processes were interviewed (St. Petersburg - 4, Moscow - 1, Kazan - 4, Hamburg - 2, Geneva - 1. Classical sociological interviews were supplemented with consultations with seven experts of social work with migrants. In addition, we analyzed texts of the recordings of nine experts speaking at round table discussions conducted at the celebration of the International Day of Migrants in Geneva on 16 December, 2017 organized by a team headed by Dr. T.-O. Gakuba.

The composition of the respondents was as follows: rrepresentatives of authorities, managers and employees of NCOs, researchers, entrepreneurs, pensioners, and an employee of an international organization. Altogether there were 15 men and 13 women, among them 10 were Russians, 10 Swiss, 4 Germans, and 2 persons had dual citizenship.

The choice of Russia and Switzerland for this study was stipulated by the specific requirements of the project. Apart from that, we interviewed some experts from Germany those who, firstly, are themselves migrants from Russia and, secondly, are engaged in studying issues in education for migrants.

\section{SOCIAL FACTORS}

The authors of the paper identified social factors that cause a widening gap, stated by experts from Russia, Switzerland and Germany, between the existing public and private educational programs and projects for migrants, institutional resources and capacities, on the one hand, and changing requirements, needs, settings of migrants' communities in the field of education on the other hand. These factors include: changes in the social structure of migrants, politicization of global migration challenges, diversification of non-national communities and groups, digitalization of the sphere of education, transformation of migrants' self-perception and self-identification. The authors conclude that there is a demand for new educational programs for non-marginalized, successful groups of non-citizens, taking into account their growing need for professional, economic, legal knowledge.

People coming from different countries and regions to Europe enter new complex social relationships with the receiving societies, communities, groups. Mass migration which affected Russia, Switzerland and other European countries in the early $21^{\text {st }}$ century has posed new challenges for the receiving countries and societies, one of the most serious of them connected with the change in the social substratum of migration. This causes the emergence of risks such as marginalization, weakening social control, the spread of deviant forms of behavior [7]. Education is the social institute which helps to form cultural identity, overcome social disintegration.

In this study, the term "migrant" is used in its broadest sense following the definition of the International Organization for Migration describing migrants as "persons, and family members, moving to another country or region to better their material or social conditions and improve the prospect for themselves or their family" [8]. This will enable us to consider various groups involved in migration processes and to compare their diverse needs, not restricting our focus by analyzing the needs of marginalized groups, such as low income migrant workers, victims of illegal people trafficking or other types of criminal activities, displaced persons, refugees, victims of armed conflicts and the like.

\section{Multi-LEVEl SOCIAL Work In FEDERATE NATIONS}

The Russian Federation and Switzerland have significant differences in the number of migrants and their proportion in the total size of the population. There are almost 12 million migrants in the Russian Federation constituting $8 \%$ of the country's population, while in Switzerland the proportion of its 2.4 million migrants is significantly higher - more than $25 \%$ of the total population. These countries differ on their state and regional policies, the organization and practices of social work, their social security mechanisms. Typical of Switzerland is the model which can be called multi-level. In it the functions of social work are distributed between the federation, cantons, local communities [9], NGOs. There are educational programs on each of these levels. In Russia, most social activities are performed, firstly, on the basis of privatepublic partnership, secondly, regions have the authority to start their own programs, plus some of the projects are initiated and carried out at the level of NGOs. The provision of education function is the prerogative of the state government and regional authorities, however, NGOs are also authorized to engage in educational activities and to offer services in education.

\section{A SCARCE OR AMPLE RESOURCE}

Overall, our study showed that education is not a scarce resource. Most of the interviewed experts were of the opinion that both in Russia and Switzerland migrants are offered educational services of different kinds. The general background against which they are provided is determined by the following common characteristics, similar challenges and problems connected with immigration processes. They are:

(1) Heterogeneity of social services provided by the regions - federal subjects in Russia and cantons in 
Switzerland - which offer to migrants social services of different scope and quality.

(2) Social work and social assistance in general, including educational programs, are intended for specific categories of migrants and their family members, mostly for representatives of those global groups of migrants who are under international protection, e.g. refugees or those who are protected by specific human rights conventions (women, children, people with disabilities).

(3) Limited distribution of the social care system and provision of the inadequate number of educational services for migrants.

(4) The multi-level structure of the state system and lack of coordination between actors on different levels engaged in providing educational services (the federal government, cantons or subjects of the federation, local communities or municipalities, NGOs or informal voluntary initiatives.

The opinions of our respondents significantly diverged in answers to the question whether education enables migrants to cope with the deficit of other forms of capital, likewise the question about what kind of education is a better asset in terms of the social status of a migrant - the one they got in their country of origin or skills and knowledge obtained in the new place of residence. Both of the countries we compare place great value on the high and highest qualifications. However, the market for them is very competitive. There is much more demand for migrants who would do the jobs requiring low or no qualification, or who would agree to fill the positions entailing their professional downgrading. Thus, for example, a university professor in the country of origin may agree to do the job of a secretary, a doctor may work as a nurse, a qualified worker - as an assistant.

To summarize, we can conclude that education, unless there is lack of it, cannot per se be secure a migrant access to resources he/she may need, a high social status or upward mobility.

\section{EDUCATION IN THE COUNTRY OF ORIGIN AND THE COUNTRY OF RESIDENCE}

As a rule, the education one received in the country of origin is not valued highly in the country chosen for residence. Exception is made for highly qualified specialists with degrees from prestigious universities and other institutions of higher education. The root of it is often not so much in the objective deficiencies but in the documents issued. It is often the case that the duration of studying, but not the content of the study programs, becomes the decisive factor. Nowadays most migrants seek to obtain qualifications in the country of prospective residence.

Answers we received to the questions about the types of educational services that are most in demand among migrants reveal the following. The provision of basic educational services, especially teaching the language of the receiving country, are fairly well organized. Social work services, other organizations working with migrants tend mostly to supply them with basic knowledge about the culture, history, legislation of the country. At the same time, a large proportion of migrants experience problems with getting other kinds of education, sometimes finding themselves in a paradoxical situation. A jobless migrant is entitled an allowance though he/she would prefer to get the qualification which would raise their prospect of finding a job. Besides, the training for the job would be less costly than social benefits. However, social services are not in the possession of the means which could be spent on migrants' education or training.

\section{VIII.EDUCATION AS APPLIED TO MIGRANTS}

Thus, given ample opportunities, only the basic educational needs are satisfied. A few Swiss experts noted that migrants themselves express their dissatisfaction with the basic education they can get (language, fundamentals of culture) whereas they require integration into the sociopolitical and economic structures. The change in their demands is connected with the transformation of migration circumstances. Whereas at the end of the $20^{\text {th }}$ and early $21^{\text {st }}$ centuries migratory processes were mostly caused by objective factors which forced people to resettle to developed countries, choosing the most favorable location as their place of residence, at present migration flows are directed through institutionalized channels. International organizations, associations, communities, tribes, diasporas, NGOs, legal entities specializing in assistance to migrants are behind this process. Now migrants or, more precisely, their organizations dictate the rules of the game, with federal, regional and local authorities and organizations increasingly succumbing to them. Also a "number of skill-targeting countries design their immigration packages and respective skill-attractive and skillselecting migration policies to benefit from the skill dividend" [10].

Education is a highly important social institute performing multiple and diverse functions among which we can name socialization, sustaining political identity, transmission of knowledge. In respect to migration education has become a crucial agent of socialization and channel of social mobility. Modern societies, including those of Russia and Switzerland, possess the capacity for differentiating education. The programs which can be offered range from the elementary, e.g. codes of behavior in receiving societies, to training for highest qualifications. Systems of education evolve under the influence of migration; there appear programs and even whole institutions which are intended for migrant audiences. They are outside the state system of education though they are supposed to comply with the existing state and regional norms. Their functions as educational establishments are becoming secondary, with advocacy campaigns and politicizing coming to the fore. 


\section{CONCLUSION}

The development of migration processes has given rise to a new generation of international migrants which is radically different from the one preceding it. "New international migrants" have the kind of education which differs from that of the "old' generation. Thanks to the World Wide Web, they have better foreign language skills, know more about the culture, customs and history of the receiving country. We witness the formation of an international migration infrastructure, a kind of migration industry. National institutes are increasingly less able to cope with the challenges of the migration crisis, delegating the issues involved to intergovernmental organizations and bodies, as well as to the supranational level (the European Union). Migrants of nowadays are not individuals, separate resettlers. They are representatives of global groups being organized to move to receiving countries. They are putting forward demands that are increasingly politicized.

Speaking about national systems of education we can say that education is one of the most conservative social institutes. It is unable to efficiently adapt to international migrants' rapidly changing needs. Private institutions' and NGOs' programs and projects are able to more flexibly respond to the emerging imperatives, often outperforming governmental institutions, thus, being more prepared to meet international migrants' needs for education, increasingly diverse and multiple.

\section{ACKNOWLEDGMENT}

The paper was prepared within the project "Creating a model of a multifunctional centre of competencies in social work with migrants under conditions of their growing inflow in Russia and Switzerland to mitigate threats to society, economy, the state" funded by the Ministry of Education and Science of the Russian Federation. The project is carried out at Saint
Petersburg State University with the support of the Federal Target Programme "Research and Development in Top Priority Dimensions of the Science and Technology Complex of Russia in 2014-2020". The Project ID is RFMEFI61317X0072.

The authors are grateful to colleagues from Haute école de travail social in Geneva (director Joëlle Libois) for supporting research, consultations and access to resources of l'Infothèque.

\section{REFERENCES}

[1] P. Bourdieu, "The forms of capital", in J. G. Richardson (ed.) Handbook of Theory and Research for the Sociology of Education, New York: Greenwordpress, 1986, pp. 241-259.

[2] A. M. Williams, V. Baláž, International Migration and Knowledge. London : Routledge, 2008. P. 29.

[3] High-skilled Migration: Drivers and Policies / edited by M. Czaika. Oxford; New York: Oxford University Press, 2018. P. 8.

[4] S. Savin, E. Moskalchuk, "Attitudes towards migrants among school students in St. Petersburg", WELLSO 2017 Volume XXXVIII, The European Proceedings of Social \& Behavioural Sciences, Future Academy, 2018, pp. 168-177.

[5] N. Ivanova, A. Kuteynikov, "Exit migration of the Magadan region resident to the «Mainland»". Sotsiologicheskie Issledovanya, № 9, 2015, pp. 80-85. (In Russian).

[6] A. Boyashov, A. Kuteynikov, "Migrant's rights at a system of the European Convention on Human Rights", WELLSO 2017 Volume XXXVIII, The European Proceedings of Social \& Behavioural Sciences, Future Academy, 2018, pp. 89-96.

[7] L. Rekhtina, N. Sokolov, A. Biblin, L. Repin, R. Akhmatdinov, "Analytical issues of risk communication. Rationale for approaches to developing research databases on radiation safety and social risks", Radiatsionnaya Gygiena = Radiation Hygiene, 2017, Vol. 10, No 4, pp. 44-52. (In Russian). DOI:10.21514/1998-426X-2017-10-4-44-5.

[8] “Glossary on Migration", 2nd ed., IOM: International Organization of Migration, № 25, 2011, p. 61.

[9] G. Martinez, T.-O. Gakuba, J. Mabillard, "L'approche communautaire avec les migrants", in: Revue d'information sociale. URL: https://www.reiso.org/articles/themes/migrations/2332-1-approchecommunautaire-avec-les-migrants (published 06.11.2017).

[10] High-skilled Migration: Drivers and Policies / edited by M. Czaika. Oxford; New York: Oxford University Press, 2018, pp.7-8. 